\title{
RESEARCH OF MOISTURE MIGRATION DURING PARTIAL FREEZING OF GROUND BEEF
}

\author{
ИССЛЕДОВАНИЕ ПЕРЕМЕЩЕНИЯ ВЛАГИ \\ ПРИ ПОДМОРАЖИВАНИИ ГОВЯЖЬЕГО ФАРША
}

\author{
Stefanovskiy V.M., Polyakov I. A., Petrov V.V. \\ The All-Russian Scientific Research Institute of Refrigeration Industry, Moscow, Russia
}

Ключевые слова: говяжий фари, подмораживание, морозильная плита, вытесняющий влагоперенос, миграция влаги.

\section{Аннотация}

Для исследования массопереноса при подмораживании пищевых продуктов морозильной плитой предложено понятие «идеальный продукт». Идеальный продукт - продукт, в котором намеренно исключено действие ряда влияющих бакторов "реального продукта» (мяса). К ним относятся: химический состав мяса; группа качества мясного сырья (NOR, DFD, PSE); криоскопическая температура, определяюшзая степень перехода воды в лед; явление осмоса; скорость замораживания и др.

С помощью понятия «идеальный продукт» и реализации его в физическом эксперименте доказано, что «пориневой эффект», вызывающий миграцию влаги, возникает за счет образования замороженной корки при подмораживании тела. В проиессе подмораживания продукта морозильной плитой «идеальная» и пищевая "реальная» среда переходят из замкнутой в открытую систему с обеспеченным подтоком влаги в незамороженную часть тела. В «идеальном продукте» возникает отжатие незамерзией еще воды от фронта замораживания, и вода выступает на поверхности тела. При этом вытеснение воды нарастает по тому же закону, по которому увеличивается толщина (масса) замороженного слоя.

При подмораживании мясного фарша влага не выступает на поверхности продукта, но вызывает увлажнение незамороженной части мяса. Причина - отжатие воды при образовании корки замораживания и влагосвязывающця способность мяса.

\section{Введение}

Обработка пищевых продуктов путем подмораживания является предметом обширных исследований как российских [1,2], так и зарубежных ученых [3, 4], основной целью которых являлось выявить преимущества этой технологии по сравнению с известными технологиями охлаждения и традиционного замораживания.

Проведенные Головкиным Н.А. и др. [1] изучение и практическая реализация субкриоскопического температурного режима хранения позволили сохранять натуральные пищевые и вкусовые достоинства продуктов и значительно увеличить допустимую продолжительность хранения подмороженных продуктов сравнительно с охлажденными.

Подмораживание - это начальная стадия замораживания продукта, которую завершают через заданный промежуток времени. Теплоту замораживания можно
Keywords: ground beef, partially freezing, freezing plate, displacement of moisture, migration of moisture.

\section{Abstract}

The concept of «ideal product» is proposed for the study of mass transfer during partial freezing of food products by freezing plate. The ideal product is a product, in which number of factors affecting the «real product» (meat) are excluded. These factors include chemical composition of meat, quality grade of raw material (NOR, DFD, PSE), cryoscopic temperature that determines the degree of water transformation into ice, the phenomenon of osmosis, rate of freezing, etc.

By using the concept of «ideal product» and its implementation in a physical experiment, it is proved that the "piston effect" causing the migration of moisture is due to frozen crust formation during partial freezing of the body.

During partial freezing of the product by freezing plate, «ideal» and «real» food environment is transformed from closed system into open one with inflow of moisture to unfrozen part of the body. In the «ideal product», there is an expulsion of unfrozen moisture from freezing front, so the water appears on the body surface. Thus, the displacement of moisture increases by the same law, according to which the thickness (weight) of frozen layer increases.

During partial freezing of ground meat, moisture does not appear on the surface of the product, but hydrates the unfrozen part of meat. The reason of this phenomenon is the expulsion of water during formation of frozen crust and water-binding capacity of meat.

\section{Introduction}

Partial freezing of food products is extensively studied by scientists in Russia [1,2] and abroad [3, 4]. The main aim of these studies is to identify the advantages of this technology compared to prior technologies of cooling and traditional freezing.

Golovkin N. A. et al. [1] conducted the study and practical implementation of subcryoscopic storage temperature that was found to maintain the natural taste and nutritional advantages of the products and to significantly increase the permissible storage time of partially frozen products compared to chilled ones.

Partial freezing is the initial stage of product freezing, which is completed after a specified period of time. During freezing, the heat may be withdrawn by cold air, boiling or 
отводить холодным воздухом, кипящей или некипящей жидкостью, льдосолевой смесью или морозильной плитой. В результате теплоотвода в поверхностном слое продукта образуется твердая замороженная корка нужной толщины, а за ней — область с температурой тела выше точки замерзания. Толщина периферийного замороженного слоя должна быть такой, чтобы при последующем внутреннем теплообмене во всем объеме тела устанавливалась температура от минус 3 до минус $2{ }^{\circ} \mathrm{C}$, равная температуре хранения.

Мясо и мясные продукты при положительной температуре условно можно рассматривать как двухфазную систему, состоящую из матрикса и воды. При отрицательной температуре - возникает более сложная, трехфазная система, состоящая из матрикса, воды и льда. Относительное количество воды, превратившейся в лед при подмораживании продуктов может составлять от 50 до 70\% от общего содержания воды в продукте $[5,6]$.

При разработке математических моделей тепломассопереноса с учетом изменения теплофизических свойств, расчете потерь массы продукта от усушки и управлении процессом подмораживания необходимо учитывать особенности, происходящие в мясе при образовании замороженной корки. Во-первых, вблизи границы фазового превращения, при понижении температуры от $+4{ }^{\circ} \mathrm{C}$ до $0{ }^{\circ} \mathrm{C}$ плотность воды уменьшается и соответственно увеличивается объем воды. Возникают гидростатические силы, которые содействуют отжатию незамерзшей еще воды от фронта замораживания. Во-вторых, по мере образования льда в мясе часть влаги отжимается за счет увеличения объема при превращении воды в лед. Эти два взаимосвязанных процесса являются причиной «поршневого эффекта», вызывающего миграцию влаги, которая изменяет функционально-технологические свойства и характеристики продукта (влагосодержание, влагосвязывающая и влагоудерживающая способность, структурно-механические и теплофизические свойства и т.д.) и увеличивает риск дополнительных потерь от усушки при подмораживании продукта.

В холодильной технологии большое внимание уделяют замороженной части продукта и условиям формирования в ней мелкокристаллической структуры льда, определяющей качество продукта. Однако, до сих пор не ясна роль влияния фазового перехода воды в лед при подмораживании на отжатие влаги в незамороженную часть продукта.

Цель работы - экспериментально проверить гипотезу о вытесняющем влагопереносе при подмораживании водосодержащих объектов.

\section{Материалы и методы}

Для обнаружения вытесняющего потока влаги, направленного от границы замораживания в незамороженную часть тела была создана экспериментальная установка, схема которой представлена на рис. 1. not boiling liquid, ice and salt mixture, or freezing plate. As a result of heat withdrawal, a hard frozen crust of desired thickness is formed in the surface layer of the product, and behind it there is an area with body temperature above the freezing point. Peripheral frozen layer thickness should be such that, in the subsequent internal heat transfer, the temperature throughout the whole body volume has the value of minus $3^{\circ} \mathrm{C}$ to minus $2^{\circ} \mathrm{C}$, which is equal to storage temperature.

Meat and meat products at a positive temperature can be conventionally considered as a two-phase system consisting of matrix and water. At a negative temperature, the more complex three-phase system occurs consisting of matrix, water, and ice. Relative amount of water turned into ice at partial freezing of food products may account $50 \%$ to $70 \%$ of total moisture content in the product $[5,6]$.

The development of mathematical models of heat and mass transfer considering the changes in thermo-physical properties, the calculation of shrinkage loss and partial freezing process control must take into account the events occurring in meat during the formation of frozen crust. First, near the phase transition boundary, where temperature is lowered from $+4{ }^{\circ} \mathrm{C}$ to $0^{\circ} \mathrm{C}$, the density of water decreases and the volume of water correspondingly increases. There are hydrostatic forces that contribute to expulsion of unfrozen water from the freezing front. Secondly, as the ice forms in meat, the part of moisture is expulsed due to volume increase during the conversion of water into ice. These two related processes are the cause of "piston effect" inducing the migration of moisture, which changes the functional and technological properties and characteristics of the product (moisture content, water-binding capacity and water-holding capacity, structural and mechanical characteristics, thermo-physical properties, etc.) and increases the risk of additional shrinkage loss during partial freezing of the product.

Refrigeration technology pays great attention to the frozen part of the product and the conditions of fine-grained ice structure formation, which determines the quality of product. However, it is still not clear how the phase transition of water into ice at partial freezing influences the expulsion of moisture to unfrozen part of the product.

The purpose of this work was to experimentally test the hypothesis of moisture displacement during partial freezing of water-containing objects.

\section{Materials and methods}

The experimental setup was created, which is shown in Figure 1, to detect the flow of moisture directed from freezing front to unfrozen part of the body. 


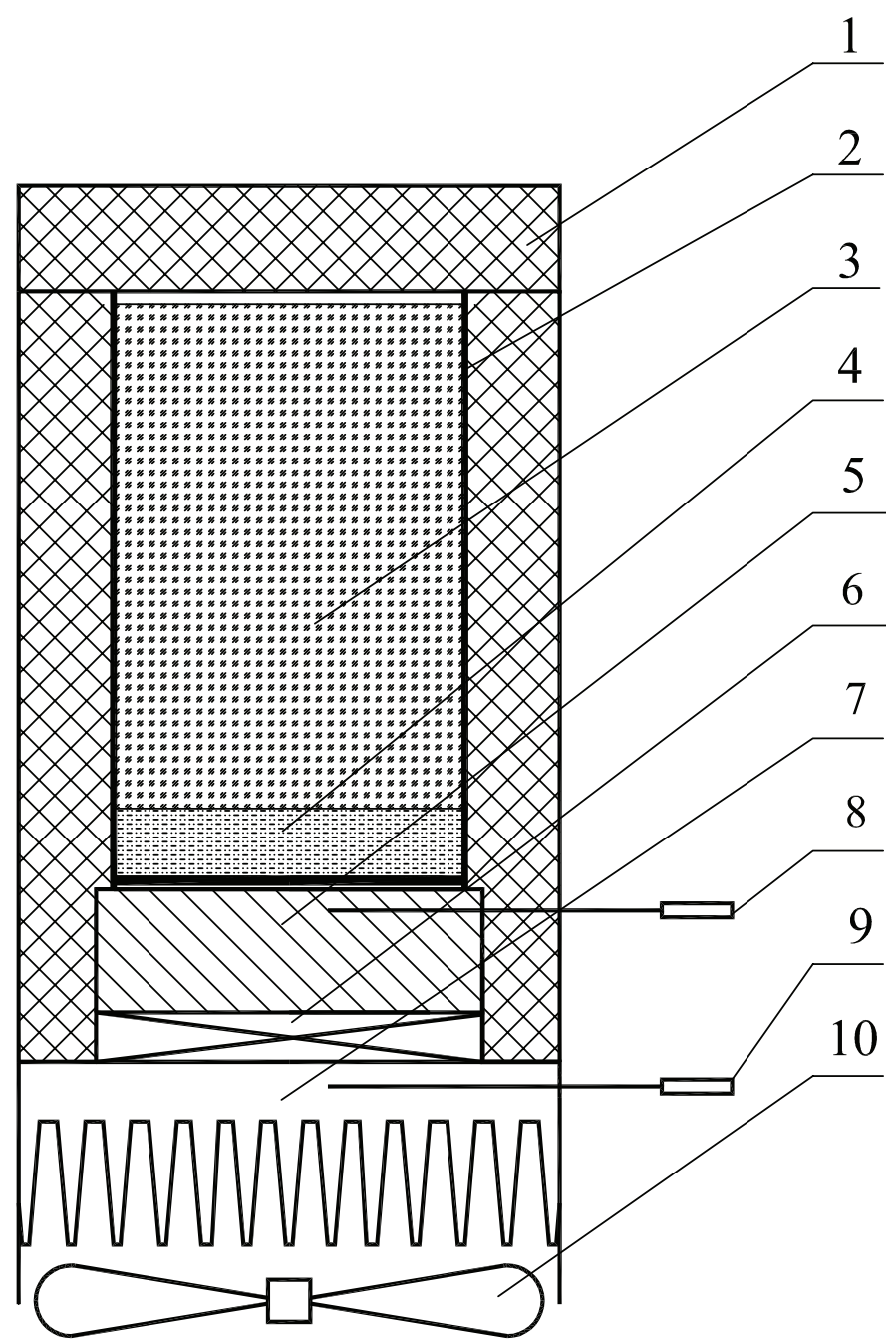

Figure 1. Experimental setup: 1 - thermal insulation; 2 - cup for frozen object; 3 - unfrozen product layer; 4 - frozen product layer; 5 - heat conductor; 6 - thermoelectric module; 7 - cooling surface of the thermoelectric module; 8, 9- temperature sensors; 10 - fan

Рис. 1. Схема экспериментальной установки: 1 - теплоизоляция; 2 - стакан для замораживаемого объекта; 3- незамороженный слой продукта; 4 - замороженный слой продукта; 5 - теплопровод; 6 - термоэлектрический модуль; 7 - теплоотводящая поверхность термоэлектрического модуля; 8, 9 - датчики температуры; 10 - вентилятор

Первоначально объектом исследования служила «модель фарша» - слой стеклянных шариков диаметром 0,001 м, размещенных в прозрачном пластиковом стакане 2 с алюминиевым дном. Внутренний диаметр стакана 0,057 м. Общая масса засыпаемых в стакан шариков и высота слоя шариков составляли 0,175 кг и 0,044 м соответственно. Свободное пространство между шариками заполняли водой $(0,0418$ кг). Во всех опытах масса шариков и воды была постоянной. Подготовленный водосодержащий образец предварительно охлаждали до $10^{\circ} \mathrm{C}$ в холодильном шкафу. Предмет исследования - процесс отжатия воды при подмораживании водосодержащей системы.

Перед началом замораживания образца поверхность верхнего слоя шариков подсушивали бумажными фильтрами под грузом (до полного исчезновения следов влаги). Затем образец устанавливали на торец алюминиевого теплопровода 5, охлаждаемого термоэлектрическим модулем TB-127-1,4-1,5 (Frost-72) и накрывали теплоизолирующим колпаком. Контроль температуры осуществляли при помощи датчи-
Initially, the object of the study was a «model of ground beef», i.e. the layer of glass beads with a diameter of 0.001 $\mathrm{m}$ placed in a clear plastic cup (2) with aluminum bottom. The inner diameter of cup was $0.057 \mathrm{~m}$. The total mass of beads in the cup and the height of beads layer were 0,175 $\mathrm{kg}$ and $0,044 \mathrm{~m}$, respectively. The free space between the beads was filled with water $(0.0418 \mathrm{~kg})$. In all experiments, the mass of beads and water was constant. The prepared water-containing sample was precooled to $10^{\circ} \mathrm{C}$ in a refrigerator. The subject of research was the process of water expulsion during partial freezing of water-containing system.

Prior to the freezing of sample, the surface of the top layer of beads was dried with paper filters under load (until moisture traces completely disappear). The sample was then installed on the flat end of the aluminum heat conductor (5) cooled by the thermoelectric module TV-127-1,4-1,5 (Frost-72) and was covered with a heat insulating cover. Temperature control was performed by means of tempera- 
ков температуры 8 и 9 (ТС-1288). Точность измерения температуры $0,2^{\circ} \mathrm{C}$. При этом датчик 8 использовался для измерения температуры теплопровода в месте контакта со стаканом, а датчик 9 - для контроля температуры горячей стороны термоэлектрического модуля.

Продолжительность подмораживания выдерживали такой, чтобы образовался замороженный периферийный слой нужной толщины,

По окончанию подмораживания измеряли толщину замороженной корки с точностью 0,5 мм, а содержимое стакана разделяли на замороженную и незамороженную части, которые взвешивали с помощью весов ВМ 1502 ОКБ ВЕСТА (НПВ =1500 г, е =100 мГ, НмПВ $=0,5$ г, $\mathrm{d}=10 \mathrm{мг}$ ).

Влагу, вытесненную за время подмораживания на поверхность верхнего слоя шариков, отделяли методом впитывания её бумажными фильтрами [7] с последующим взвешиванием с точностью 0,001 г.

На втором этапе исследования в качестве объекта выбран говяжий фарш. Перед началом подмораживания охлажденное мясо разрезали на небольшие кусочки, измельчали их на электомясорубке Straune и фарш тщательно перемешивали. Замораживающий стакан наполняли фаршем и помещали в холодильный шкаф для выравнивания температуры до $10^{\circ} \mathrm{C}$. Последующие операции выполняли также, как и с образцом, содержащим стеклянные шарики.

Массовую долю влаги мясного фарша определяли перед замораживанием $\left(W_{0}\right)$ и после заданной продолжительности подмораживания. При этом пробы отбирали в разных точках по высоте незамороженной части образца и после определения влажности вычисляли среднее значение $\left(W_{c p}\right)$. По величине $\left(W_{c p} / W_{0}\right)$ - оценивали относительное увлажнение незамороженной части фарша за время подмораживания. Определение массовой доли влаги проводили методом высушивания при $105^{\circ} \mathrm{C}$ в аппарате MOISTURE ANALYZER ML-50, A\&D Co., LTD (0,1\% / Max 51 g).

\section{Результаты и обсуждение}

В соответствии с современными системными воззрениями при изучении холодильных технологий используют различные виды моделей (физические, математические, морфологические, функциональные, информационные и др.), отображающие определенную группу свойств системы. При этом выбор альтернативных средств реализации технологических функций осуществляют на разных уровнях абстрагирования $[8,9]$. В истории науки немало примеров введения понятий и использования, так называемых, «идеальных моделей» (идеальный газ, идеальный компрессор, обратимый процесс и др.). Мы предлагаем понятие «идеальный продукт», в котором намеренно исключено действие ряда влияющих факторов «реального продукта» (мяса). К ним относятся: ture sensors (8 and 9) (TC-1288). Temperature measurement accuracy was $0,2^{\circ} \mathrm{C}$. The sensor 8 was used to measure temperature of heat conductor in the point of contact with cup, and the sensor 9 was used to control the temperature of the hot side of thermoelectric module.

The duration of partial freezing was such that the frozen peripheral layer of desired thickness has been formed. Upon completion of partial freezing, the frozen crust thickness was measured with an accuracy of $0.5 \mathrm{~mm}$, and the contents of the cup was separated into the frozen and unfrozen parts that were weighed with BM 1502 OKB VESTA scales (upper weight limit $=1500 \mathrm{~g}, \mathrm{e}=100 \mathrm{mg}$, lower weight limit $=0.5 \mathrm{~g}, \mathrm{~d}=10 \mathrm{mg}$ ).

Moisture displaced during partial freezing to the surface of the top layer of beads was separated by soaking it with paper filters [7] followed by weighing them with an accuracy of $0.001 \mathrm{~g}$.

At the second stage of experiment, ground beef was selected as the object of the study. Prior to partial freezing, the chilled meat was cut into small pieces and minced with Straune electric mincing machine. Then the ground beef was mixed thoroughly. Cup was filled with ground beef and placed in a refrigerator for temperature equalization at the level of $10{ }^{\circ} \mathrm{C}$. Subsequent operations were carried out in the same way as with the sample containing glass beads.

The moisture content of ground beef was determined prior to freezing $\left(W_{0}\right)$ and after the predetermined duration of partial freezing. The samples were taken at different points along the height of the unfrozen part of the sample and, after determination of moisture content, an average value was calculated $\left(W_{c p}\right)$. The value $\left(W_{c p} / W_{0}\right)$ was used to evaluate the relative hydration of the unfrozen part of ground beef during partial freezing. Determination of moisture content was carried out by drying at $105^{\circ} \mathrm{C}$ in MOISTURE ANALYZER ML-50, A\&D Co., LTD (0,1\% / Max 51 g).

\section{Results and discussion}

In accordance with current knowledge, the studies of refrigeration technologies use different types of models (physical, mathematical, morphological, functional, informational, etc.) representing a certain group of system properties. The selection of alternative means for implementation of technological functions is carried out at different levels of abstraction $[8,9]$. In the history of science, there are many examples of concepts introduction and use of so-called «ideal models» (ideal gas, ideal compressor, reversible process, etc.). We propose the concept of «ideal product», in which number of factors affecting the «real product» (meat) are excluded. These factors include: 
- Химический состав мяса;

- Группа качества мясного сырья: NOR (нормальное), DFD (Dark, Firn, Dry) - темное, твердое, сухое и PSE (Pale, Soft, Exsudative) - бледное, мягкое, водянистое;

- Криоскопическая температура мяса, определяющая степень перехода воды в лед;

- Явление осмоса;

- Скорость замораживания и др.

В качестве «идеального продукта» и физической модели говяжьего фарша выбран слой стеклянных шариков, свободное пространство между которыми заполнено водой.

Ранее нами установлено [10], что при подмораживании мяса морозильной плитой толщина замороженной корки $\xi$ нарастает в соответствии с уравнением $\xi=\beta \sqrt{\tau}$, где $\beta-$ постоянный коэффициент, $\tau-$ продолжительность процесса подмораживания мяса.

В случае адекватности модели «идеального продукта» данные по его подмораживанию, представленные в координатах $\xi^{2}$ от $\tau$, должны группироваться на прямой линии, проходящей через начало координат.

Результаты, полученные по подмораживанию водосодержащего слоя стеклянных шариков, свидетельствуют, что толщина замороженного слоя в квадрате линейно изменялась со временем (рис. 2), и модель «идеального продукта» адекватна.
- Chemical composition of meat;

- Quality grade of raw material: NOR (normal meat), DFD (Dark, Firm, Dry meat) and PSE (Pale, Soft, Exudative meat);

- Cryoscopic meat temperature that determines the degree of water transformation into ice;

- The phenomenon of osmosis;

- Rate of freezing, etc.

The layer of glass beads, the space between which is filled with water, is selected as the «ideal product» and as the physical model of ground beef.

We have previously established [10] that, during the partial freezing of meat by freezing plate, the thickness of frozen crust $\xi$ increases according to the equation $\xi=\beta \sqrt{\tau}$, where $\beta$ is a constant factor, and $\tau$ is the process duration of meat partial freezing.

In the case of «ideal product» model adequacy, the data on its partial freezing represented in the coordinates of $\xi^{2}$ vs $\tau$ should be grouped together in a straight line passing through the origin of coordinates.

The results obtained by partial freezing of water-containing layer of glass beads indicate that the squared thickness of the frozen layer varies linearly against time (Fig. 2) and the «ideal product» model is adequate.

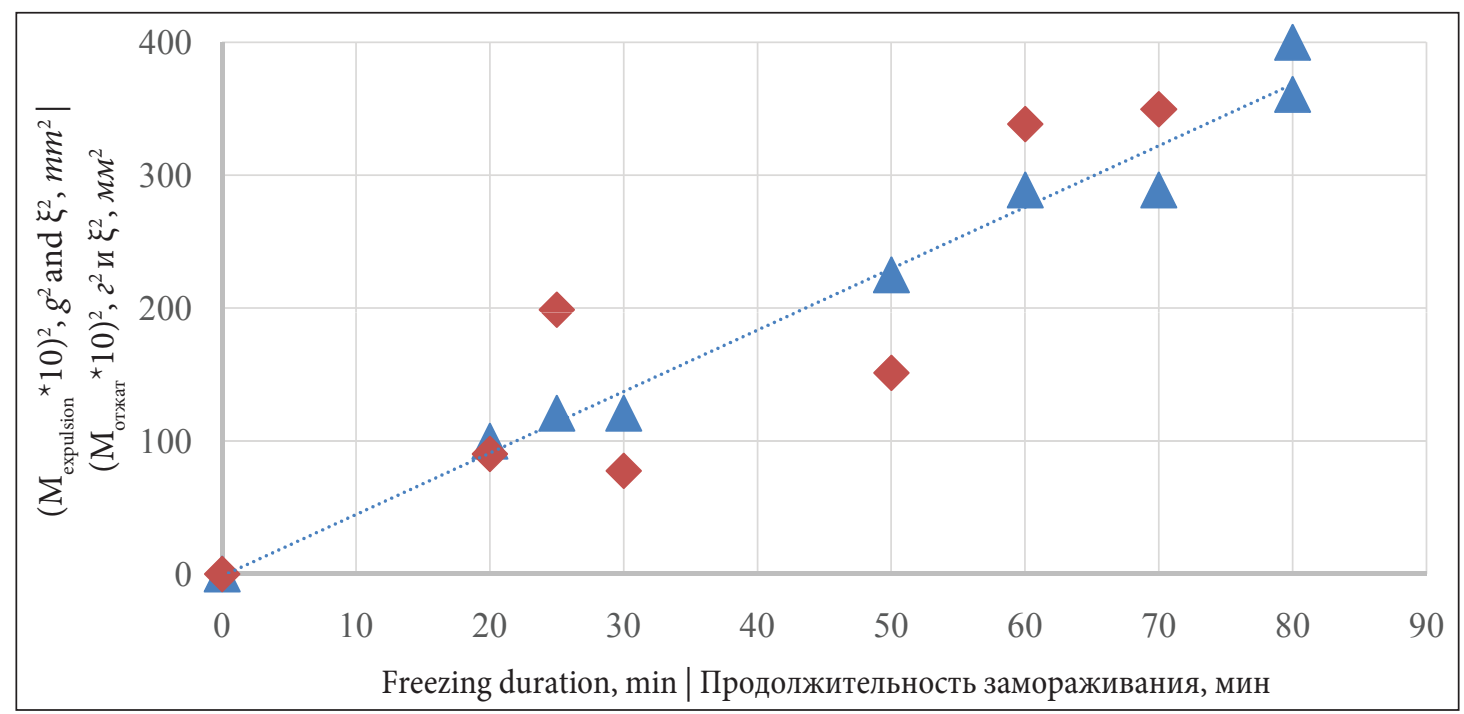

Figure 2. Comparison of patterns for increase of frozen crust thickness (triangles) and the mass of expulsed water (rhombuses) during the partial freezing of «ideal product» by freezing plate

Рис. 2. Сравнение закономерности нарастания толщины замороженной корки (треугольники) и массы отжатой воды (ромбы) при подмораживании морозильной плитой «идеального продукта»

Другой, наиболее важный для данной ситуации вывод заключается в том, что количество вытесненной воды нарастало по тому же закону, по которому увеличивалась толщина (масса) замороженного слоя. Таким образом, количество вымороженной массы в теле является ключевым фактором, определяющим состояние увлажнения незамороженной части продукта.
Another most important conclusion for this situation is that the amount of displaced moisture increases by the same law, according to which the thickness (weight) of frozen layer increases. Thus, the amount of frozen mass in the body is a key factor determining the state of hydration of the unfrozen part of the product. 
Громли и др. [11, 12] исследовали влияние температурных режимов хранения ряда пищевых продуктов, при температурах минус 60, минус 30 и температурных колебаниях $-30>-10>-33^{\circ} \mathrm{C}$. В частности, при замораживании пиццы, обсыпанной сыром, измерения проводили на верхней половине каждого коржика, и авторы обратили внимание на то, что «...пицца, выдержавшая режим колебаний температуры имела самое высокое содержание влаги (38.6, 38.0 и 40.0\%), что наводит на мысль о перемещении влаги из верхней части коржика» [11]; при этом авторы работы не дали объяснения происходящему физическому явлению.

Наши наблюдения и измерения показали, что в отличии от «идеального продукта» появление отжатой влаги на поверхности «реального продукта» - говяжьего фарша - не происходит. Если предположить, что отжимаемая влага связывается и удерживается мясным фаршем, то это должно приводить к увлажнению его незамороженной зоны.

Результаты проведенных экспериментов свидетельствуют, что массовая доля влаги в незамороженной зоне подмораживаемого фарша становилась тем больше, чем больше толщина замороженного слоя (рис. 3). Следовательно, процесс вытесняющего массопереноса сопутствует замораживанию и только ему свойственно.
Gormley et al. [11, 12] studied the effect of temperature modes during the storage of different food products at temperatures of minus 60 , minus 30 , and temperature variations of $-30^{\circ} \mathrm{C}$ to $-10^{\circ} \mathrm{C}$ to $-33^{\circ} \mathrm{C}$. In particular, when freezing the pizza with cheese the measurements were performed on the upper half of each cake and the authors noted that «...the pizza bases from the fluctuating regime had the highest moisture content $(38.6,38.0,40.0 \%)$ and suggests moisture migration from the topping. The treatments had no effect on moisture content in the bottom half of the base (mean $38.6 \%$ ), or in the topping (mean $53.6 \%) . .$. [11]; although, the authors of the work did not give an explanation for that physical phenomenon.

Our observations and measurements showed that, in contrast to the "ideal product", the appearance of expulsed moisture on the surface of the "real product», i.e. beef ground beef, did not take place. Assuming that the expulsed moisture is bound and held by the ground meat, this fact should lead to hydration of unfrozen parts of the product.

The experimental results show that the greater the thickness of frozen layer in partially frozen ground beef the greater the moisture content in its unfrozen part (Fig. 3). Consequently, the freezing is accompanied by mass transfer due to displacement of moisture, which is characteristic only of freezing.

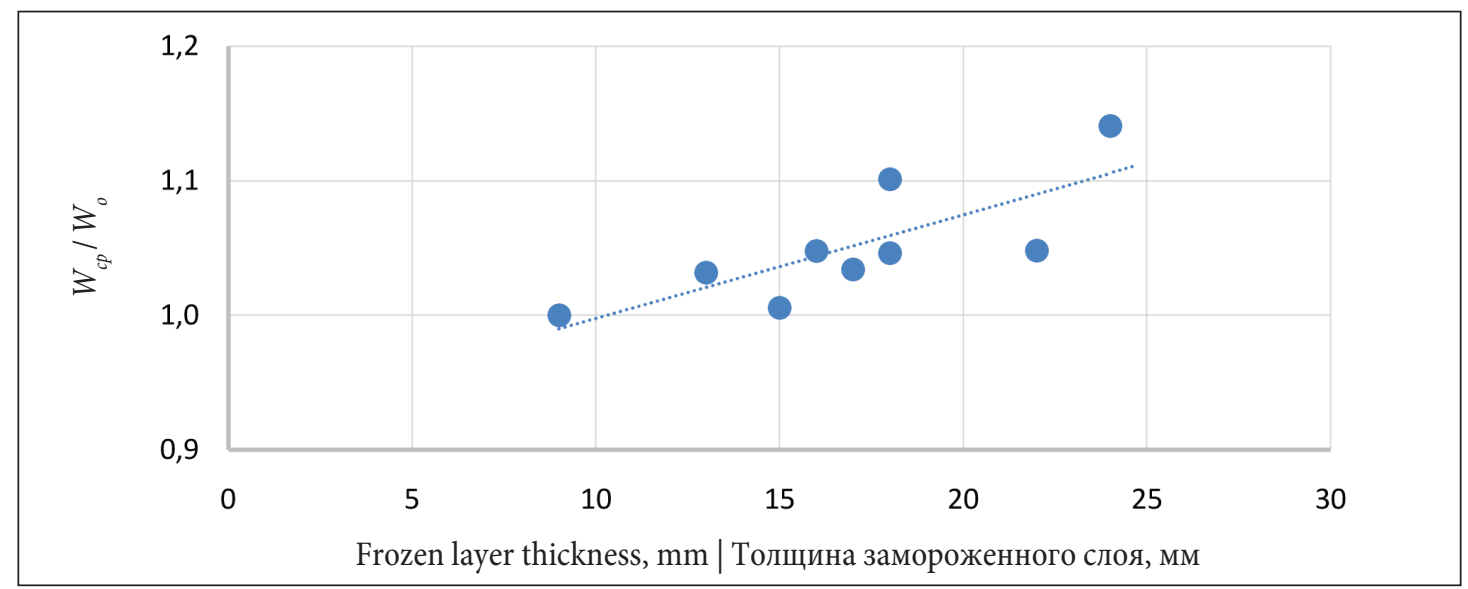

Figure 3. Change in moisture content in the unfrozen part of ground beef against the frozen layer thickness during the partial freezing Рис. 3. Изменение относительной влажности незамороженной части говяжьего фарша от толщины замороженного слоя при подмораживании

Анализ опытных данных о массопереносе, сопровождаемый оценкой динамики льдообразования, значительно дополняет и расширяет общую картину тепломассообменных явлений, происходящих при подмораживании мясного фарша морозильной плитой, и подтверждает гипотезу о вытесняющем массопереносе при фазовом переходе водосодержащих систем.

\section{Выводы}

С помощью предложенного понятия «идеальный продукт» и реализации его в физическом эксперименте доказано, что «поршневой эффект», вызывающий
Analysis of experimental data on the mass transfer followed by assessment of ice formation dynamics significantly complements and enhances the overall picture of heat and mass transfer occurring during partial freezing of ground meat by freezing plate. Also, it confirms the hypothesis of mass transfer due to displacement of moisture during the phase transition of water-containing systems.

\section{Conclusions}

By using the concept of «ideal product» and its implementation in a physical experiment, it is proved that the "piston effect» causing the migration of moisture is due 
миграцию влаги, возникает за счет образования замороженной корки при подмораживании тела.

Подмораживание «идеального продукта» вызывает перенос влаги на поверхность незамороженной части тела.

При подмораживании мясного фарша образующаяся замороженная корка отжимает часть влаги в незамороженную зону фарша, соответственно повышая его влажность.

БИБЛИОГРАФИЧЕСКИЙ СПИСОК 1. Головкин Н.А., Маслова Г.В., Скоморовская И.Р. Консервирование продуктов животного происхождения при субкриоскопических температурах. - М.: Агропромиздат, 1987. C. 272.

2. Чижов ГБ. Теплофизические процессы в холодильной технологии пищевых продуктов. - М.: Пищевая промышленность, 1979. - C. 271.

3. Frozen Food Science and Technology. Edited by Judith A. Evans. - Food Refrigeration and Process Engineering Research Centre (FRPERC) University of Bristol, UK: Blackwell Publishing, 2009. - P. 368.

4. Stonehouse G.G., Evans J.A. The use of supercooling for fresh foods: A review //Journal of Food Engineering. -2015 . T. 148. - P. 74-79.

5. Riedel L. Kalorimetrische Untersuchungen über das Gefrieren von Fleisch. // Kältetechnik. - 1957. - № 2. - P. 38-40.

6. Рютов А.Г. Влияние связанной воды на образование мьда в пищевых продуктах при их замораживании. // Холодильная техника. - 1976. - № 5. - С. 32-37.

7. Trout G.R. Techniques for measuring water-binding capacity in muscle foods - a review of methodology // Meat Science. 1988. - 23. - P. 232-235

8. Stefanovskiy V. M. Processes and Technological Systems for Freezing of Foodstuff. // Handbook of Research on Advances and Applications in Refrigeration Systems and Technologies (2 Vols.) / edi. Pedro Dinis Gaspar (University of Beira Interior, Portugal) and Pedro Dinho da Silva (University of Beira Interior, Portugal). - Chicago: IGI Global, 2015. - P. 412-432. DOI: 10.4018/978-1-46668398-3.

9. Стефановский В.М., Тимофеева Н.М., Стефановская Н.В. Сокращение усушки мяса при холодильной обработке (Прогнозное исследование). - М.: ВНИИПИ, 1989. - С. 65.

10. Стефановский В.М., Поляков И.А., Петров В.В. Подмораживание мяса морозильной плитой. // Холодильная техника. - 2016. - № 2. - С. 55-58.

11. Gormley T.R., Brennan M. \& Butler F. Upgrading the cold chain for consumer food products. - Dublin: Teagasc Press, 2000. - P. 32.

12. Gormley R., Walshe T., Hussey K., \& Butler F. (2002). The effect of fluctuating vs. constant frozen storage temperature regimes on some quality paramets of selected food products. Lebensmittel-Wissenschaft und Technologie - Food Science and Technology, 35 (2), 190-200. doi:10.1006/fstl.2001.0837 to frozen crust formation during partial freezing of the body.

Partial freezing of «ideal product» causes the transfer of moisture to the surface of the unfrozen part of the body.

During partial freezing of ground meat, the frozen crust formed expulses part of moisture to the unfrozen area of the product, correspondingly increasing its moisture content.

\section{REFERENCES}

1. Golovkin N.A., Maslova G.V., Skomorovskaya I.R. Frozen animal products at subcryoscopic temperatures. - M.: Agropromizdat, 1987. - P. 272

2. Chizhov G. B. Thermal processes in the food refrigeration technology. - M.: Food Industry, - 1979. - P. 271.

3. Frozen Food Science and Technology. Edited by Judith A. Evans. - Food Refrigeration and Process Engineering Research Centre (FRPERC) University of Bristol, UK: Blackwell Publishing, $-2009 .-P .368$.

4. Stonehouse G.G., Evans J.A. The use of supercooling for fresh foods: A review //Journal of Food Engineering. - 2015. T. 148. - P. 74-79.

5. Riedel L. Kalorimetrische Untersuchungen über das Gefrieren von Fleisch. // Kältetechnik. - 1957. - № 2. - P. 38-40.

6. Riutov D. G. Influence of bound water on ice formation in foodstuffs during their freezing. Refrigeration technology. 1976. - № 5. - P. 32-37.

7. Trout G. R. Techniques for measuring water-binding capacity in muscle foods - a review of methodology // Meat Science. 1988. - 23. - P. 232-235.

8. Stefanovskiy V. M. Processes and Technological Systems for Freezing of Foodstuff. // Handbook of Research on Advances and Applications in Refrigeration Systems and Technologies (2 Vols.)/ edi. Pedro Dinis Gaspar (University of Beira Interior, Portugal) and Pedro Dinho da Silva (University of Beira Interior, Portugal). - Chicago: IGI Global, 2015. - P. 412-432. DOI: 10.4018/978-1-46668398-3.

9. Stefanovskiy V.M., Timofeeva N.M., Stefanovskaya N.V. Reducing shrinkage of meat during the cooling treatment (Predictive research). - M.: VNIIPI, 1989. - P. 65.

10. Stefanovskiy V.M., Polyakov I.A., Petrov V.V. Meat partial freezing using a freezing plate. Refrigeration technology. 2016; (2): P. 55-58.

11. Gormley T.R., Brennan M. \& Butler F. Upgrading the cold chain for consumer food products. - Dublin: Teagasc Press, 2000. - P. 32.

12. Gormley R., Walshe T., Hussey K., \& Butler F. (2002). The effect of fluctuating vs. constant frozen storage temperature regimes on some quality paramets of selected food products. Lebensmittel-Wissenschaft und Technologie - Food Science and Technology, 35 (2), 190-200. doi:10.1006/fstl.2001.0837 


\section{СВЕДЕНИЯ ОБ АВТОРАХ}

Принадлежность к организации

Стефановский Владимир Михайлович - доктор технических наук, профессор, главный научный сотрудник, Всероссийский научно-исследовательский институт холодильной промышленности 125422, Москва, ул. Костякова, д. 12.

Тел.: 8-495-253-15-74

E-mail: stef-vm@yandex.ru

Поляков Игорь Алексеевич - старший научный сотрудник лаборатории холодильного оборудования, Всероссийский научноисследовательский институт холодильной промышленности

125422, Москва, ул. Костякова, д. 12.

Тел.: 8-910-457-77-89

E-mail: hsh05@yandex.ru

Петров Владимир Владимирович - старший научный сотрудник, заведующий лабораторией холодильного оборудования, Всероссийский научно-исследовательский институт холодильной промышленности.

125422, Москва, ул. Костякова, д. 12.

Тел.: 8-909-976-84-22

E-mail: bestprofile@yandex.ru

\section{Критерии авторства}

Стефановский В.М. разработал методологию исследования, участвовал в проведении экспериментов, провел анализ полученных данных и занимался описательной частью.

Поляков И.А. сконструировал и изготовил экспериментальную установку, проводил исследование по динамике подмораживания водосодержащего слоя стеклянных шариков и мясного фарша, и занимался описательной частью.

Петров В.В. участвовал в создании экспериментальной установки, в обсуждении результатов, корректировал рисунки к рукописи до подачи в редакцию.

Ответственность за работу и предоставленные сведения несут все авторы.

\section{Конфликт интересов}

Авторы заявляют об отсутствии конфликта интересов.

Поступила 12.10.2016

\section{AUTOR INFORMATION}

Affiliation

Stefanovskiy Vladimir Michailovich - doctor of technical sciences, professor, chief research scientist, The All-Russian Scientific Research Institute of Refrigeration Industry

125422, Moscow, Kostyakova str., 12

Tel.: 8-495-253-15-74

E-mail: stef-vm@yandex.ru

Polyakov Igor Alekseevich - senior research scientist, Refrigeration equipment laboratory, The All-Russian Scientific Research Institute of Refrigeration Industry

125422, Moscow, Kostyakova str., 12

Tel.: 8-910-457-77-89

E-mail: hsh05@yandex.ru

Petrov Vladimir Vladimirovich - senior research scientist, head of Refrigeration equipment laboratory, The All-Russian Scientific Research Institute of Refrigeration Industry

125422, Moscow, Kostyakova str., 12

Tel.: 8-909-976-84-22

E-mail: bestprofile@yandex.ru

\section{Contribution}

Stefanovskiy V. M. developed the research methodology, participated in conduction of experiments, carried out the data analysis, and worked with narrative.

Polyakov I. A. designed and manufactured experimental setup, carried out the experiments on the partial freezing dynamics of watercontaining layer of glass beads and ground meat, and worked with narrative.

Petrov V. V. participated in the manufacturing of the experimental setup and in the discussion of results, corrected the figures in the manuscript before submission to the editor.

All the authors are responsible for the work and the information provided.

\section{Conflict of interest}

The authors declares no conflict of interest.

Received 12.10.2016 